\title{
Acquisition of Sentence by a Three-Year-Old Indonesian Boy A Case Study on M. Gentamas Ransi Alden
}

\author{
Fadhila Hayani ${ }^{1, *}$ Siti Aisyah Ginting ${ }^{2}$ Rahmad Husein ${ }^{3}$
}

\author{
${ }^{1}$ English Applied Linguistic Study Program, Post-Graduate, State University of Medan \\ ${ }^{2}$ State University of Medan \\ ${ }^{3}$ State University of Medan \\ *Corresponding author. Email: fadhilahayani@gmail.com
}

\begin{abstract}
This study deals with the acquisition of sentences by three-year-old child Indonesian boy on M. Gentamas Ransi Alden. The objective of this study were to investigated the sentences that produced by three-year-old Indonesian boy that can be acquired in mood, in a case study on M. Gentamas Ransi Alden. This research was conducted by using descriptive qualitative research design. The data were utterances from a three-year-old Indonesian boy and source of data taken from M. Gentamas Ransi Alden^s utterances. The result of the data showed that the subject already acquired the sentences based on mood, they are: 1) Declarative sentences, 2) Imperative sentences, 3) Exclamatory sentences, and 4) Interrogative sentences.
\end{abstract}

Keywords: language acquisition, types of sentence, a three-year-old Indonesian boy.

\section{INTRODUCTION}

Human growth and development requires a long time and consists of the phases that have their own characteristics. Among the phases, the initial growth phase or the growth rate of child is a phases that need a great attention because it has significance for human growth and development in the next period, especially in the aspects of language acquisition. Considering that language acquisition is an important aspect that marks the phase of growth and development of a child. Talk about language acquisition in child is more interesting to be discussed considering not many people observe (especially the ordinary people including parents who raise their child). How the actual language acquisition in child occurred. We just know suddenly when a child is able to speak. Never previously imagined how utterances were acquired and ultimately used by a child as a tool to communicate.

This process of language acquisition is the mastery of language that takes place naturally through daily communication without having to go through special teaching. At the beginning of the acquisition of language usually the child will be more silent, listening, paying attention, and imitating what he listens to. However, after the age increases, the growth of the tool said the child can be known by the more perfect speeches produced by the child. The process of acquiring language is a controversial matter between linguists. The issue that is debated is the acquisition of language that is nurture, namely the acquisition is determined by the nature of the environment.

The subject in this study is a boy. He is three years old. Since his school, he can speak Indonesian language. But, his language spoke still using a formal form of Indonesia language. For example, when Tamas saw his father bought a new clothe, he asked his father;

T: "Ayah membeli baju baru ya?"

T: Baju baru yang Ayah beli untuk siapa?"

Based on the sentence above, a child at his age does not use a formal language like him.

Based on the relevant study and the phenomenon above, the writer interested to investigate what types of sentences that acquired by child.

\section{REVIEW OF LITERATURE}

\subsection{Language acquisition}

Language acquisition is the process whereby child achieves a fluent control of their native language [11]. Child learns a language, not because they are subjected to a similar conditioning process, but because they possess an inborn capacity which permits them to acquire a language as a normal maturational process. 
This capacity is universal. The child has an innate language acquiring device. He learns a language by exposure to it in society and by unconsciously forming certain hypothesis about language, which he goes on modifying till he comes to the adult model to which he is for the most part exposed. So the child goes on constructing an innate grammar, operating over generalized rules. The capacity for acquiring language is remarkable a number of reasons.

\subsection{Steps in Language Acquisition}

When humans are born, start from baby, the simple and effective methodology of grammatically judgment is difficult or impossible to apply with young child. It is because he does not have the grammatical of his first language in his brain and completely with its rules. The native language is acquired through some stages and every stage is passed near to adult's language. There are six stages in child's first language acquisition; Pre-talking stage/ cooing (0 - 6 months), babbling stage ( $6-8$ months), holophrastic stage ( 9 18 months) [6], the two-word stage (18 - 24 months), telegraphic stage (24 - 30 months), later multiword stage (30+ months) [5].

\subsection{Theories of Language Acquisition}

The way child acquire the language is, broadly, divided into three theories, namely behavioristic, nativistic, and cognitiveistic.

1. Behavioristic theory emphasizes that the acquisition of language in child due to the teaching of the surrounding environment. Child are viewed as having no supplies whatsoever and acquiring knowledge from the environment [4].

2. Nativistic theory states that child can acquire and develop language skills because they have what is called innate language faculty or better known as Language Acquisition Device (LAD) [5].

3. Cognitive theory, in relation to language acquisition, is a theory that accommodates the previous two theories. Cognitive theory views language acquisition as the result of mental work and is based on the child's cognitive capacity to discover the structure of language through the surrounding environment. Cognitive theory asserts that nature and organisms is an inseparable functional unit. Thus, cognitive theory recognizes the existence of human innate potential while paying attention to aspects of the environment around the child.

\subsection{Sentence Acquisition}

There are many children who are born mute. People like this are born with crippled (due to brain injuries) or on some other abnormalities found in the organs of articulation as the tool said. A child who silent but heard can develop the ability to produce speech, however, how the child can understand a sentence? Well, they can understand a sentence that reflects the main characteristics of the language, i.e. the understanding of a number of sentence grammar is not limited. Comprehension and production process that always tries to follow the understanding because the child acquire a language aspect in understanding, then the child can try to figure out how to use it in production.

\subsection{Types of sentences}

A sentence is a group of word at least consists of subject and predicate and has an idea. Shopen divided sentence into declarative sentence, interrogative sentence, imperative sentence, and exclamatory sentence. The types of these simple sentences above are based on the function of the sentence [10].

\section{METHODOLOGY}

This study applied descriptive qualitative research design by describing the sentence of language acquisition [2]. In this case the answer of the problem by giving explanation. The data was the utterances of a child three-year-old boy from the conversation to his family members. The study was conducted from a child three-year-old Indonesian boy. The data of this study were the transcript of the video recorded utterances which had been gathered from conversation between his and his family members. The data were analyzed by applying analysis model which consisted of three steps namely; 1) data condensation, 2) data display, and 3) conclusion drawing and verification [8]. The data were synthesized based on Shopen theory [10].

\section{FINDINGS AND DISCUSSION}

After analyzing the data, there are four types of sentences that had been uttered by a child three-year-old Indonesian boy.

\subsection{Declarative Sentence}

Declarative sentences are conventionally and typically used for speech acts such as claiming, stating, but also accusing, criticizing, promising, and guaranteeing, reporting, complaining and bragging, but also acts of predicting and promising. In this study, the researcher found stating, reporting, and criticizing [10].

\subsubsection{Stating}

Data St1/ Tm

Tm : taka da saus, tak da saus, ada ketju, ada ditatatsun, dan ada ten cheeses.

Tak ada saus, taka da saus, ada keju, ada disusun, dan ada ten cheeses.

(There is no sauce, no sauce, there is cheese on it, and there are ten cheeses)

The data was taken on March 13, '21 when he is eating. This context is when his mother gave him a food. He tried to smell the aroma and touch the food. Tm was smelled the food and he stated there is no sauce and there are ten cheeses. It can be conclude that $\mathrm{Tm}$ acquired a declarative sentence, and Tm use the sentence is to stating "taka da saus, tak da saus, ada ketju, ada ditatatsun, dan ada ten cheeses" about his food. 


\subsubsection{Reporting}

Data Rp1/ Tm

Tm: (diam) ibu sayun, amas matan kelot (ibu sayur, Tamas makan carrot) (mam, I am eating carrot)

The data was taken from $\mathrm{Tm}$ and $\mathrm{Mm}$ conversation on March 3, 2021 at their house. The occasion is when $\mathrm{Tm}$ was eating and $\mathrm{Mm}$ looks then asked what he was eating. Tm said to the huckster that he was eating carrot. In this sentence, "ibu sayun, amas matan kelot", Tm use a declarative to represent or reporting that he eats the vegetables to huckster.

\subsubsection{Criticizing \\ Data $\mathrm{Ct} / \mathrm{Mm} / \mathrm{Tm}$ \\ $\mathrm{Mm}$ : Kenapa? \\ Why? \\ Tm : $\quad$ Itu tepe \\ (that is tempe) \\ $\mathrm{Mm}$ : Oh iya.... Cabbage.... \\ (it is true, that's cabbage) \\ Tm : Itu onion! \\ (that is onion!) \\ $\mathrm{Mm}$ : Onion? Oh iya.... Onion... iya gak, nggak, nggak.... Onionnya ga usah dimakan. \\ (onion? Right, that's onion. Don't eat it!)}

The data was taken on March 3, 2021 between Tm and $\mathrm{Mm}$ conversation. This context continued from data above, this happened when Tm is eating tempe and his mom misunderstand with Tm's sentence before. Mm think Tm said "cabbage", and Tm repeat what he said before, it is "onion", not "cabbage" or "tempe". From this sentence, "Itu onion!", show a Tm's declarative sentence to criticize his mom sentence.

\subsection{Interrogative sentences}

Interrogative sentences are conventionally associated with the speech act of requesting information, asking questions, introducing deliberations, etc [10]. Interrogative sentence here can be used for directive speech act.

\section{Data Int/ Mm/ Tm \\ Mm : Hai Tamas \\ (Hi, Tamas)}

Tm : Hai, tamu mau temana?

(Hi, where are you going?

The data was taken on March 14, 2021. This conversation occurred when Tm and family is on the way. They wanted to go to Bukit Lawang. The context showed Mm greeted Tm, and Tm respons it, and ask his mother "tamu mau temana". In this context Tm use interrogative sentence to ask where she to go is.

\subsection{Exclamatory Sentence}

Exclamatory sentences are like declarative sentences in that they make a statement instead of asking a question, but their main purpose is to express strong emotion. They are easily recognized because they end in an exclamation point instead of a period.

Data Ex/ Tm/ Mm

$\mathrm{Tm}$ : I want to eat my biscuit

$\mathrm{Mm}$ : Mommy throw away your biscuit

This conversation is between subject and his mother, through this exclamatory sentence Tm want to show his strong emotion to his mother that he wants to eat his biscuit, "I want to eat my biscuit". And this conversation occurred April 18, 2021 when Tm wants to eat his biscuit.

\subsection{Imperative Sentence}

Imperative sentences have their basic use in all attempts to get or advise the hearer to do something [10]. For imperative sentence, it can be used for directive speech act.

\author{
Data $\mathrm{Im} / \mathrm{Tm}$ \\ Tm: mama denan tu suana ajan, yok ambil \\ wuduk haha abis tu shonlat. \\ (mama dengar tu suara adzan, yok ambil \\ wudhu haha abis tu sholat) \\ (Mommy, listen! It is adzan, (laughing) \\ let's go to pray!)
}

The next imperative sentence that acquired by subject can be seen in Tm145. In this conversation can be seen that Tm asked his mother to take wudhu for prepare to take salat, "mama denan tu suana ajan, yok ambil wuduk haha abis tu shonlat". This is occurred on April 28, 2021, he uses imperative sentence to ask mommy to do something together.

Based on the analyzed above, the writer conclude that from Arizona was found that children of the three years old are able to acquire all kinds of sentences, they are: declarative, imperative, negative, exclamation sentence [1]. Which the dominant they use are declarative, active and simple sentence. Another study also talked about with the same interest. Salnita was analyzed a child 3 year old based on the level of phonology, syntax, and semantics. At the syntactic level, the subject of research has been able to test four types of sentences, namely declarative, imperative, interrogative, and exclamation sentences [9].

This research find out the three years old children was acquired some types of sentences, they are: 1) Declarative sentences, 2) Interrogative sentences, 3) Exclamatory sentences and 4) Imperative sentences, and the subject is going process to develop to another type of sentence such as complex sentence. From those four types of sentences the subject dominantly acquired about declarative sentence than another types of sentence. In declarative sentence, the subject was used stating, reporting, and criticizing sentence.

\section{CONCLUSION}

It is found that all the four types of sentence occurred in a sentence from a child three-year-old 
Indonesian boy namely; declarative sentence, interrogative sentence, exclamatory sentence, and imperative sentence. In declarative sentence, this study found stating, reporting, and criticizing sentence.

\section{AUTHORS' CONTRIBUTIONS}

The results of this research are focused on syntactic level, this study is for add up new horizons in it. In addition, hopefully, the findings will explore the new ideas for other researchers in investigating the language acquisition by a three-year-old, and also be able to give much contribution for the further research about the same topic concerning complex sentences acquisition of five years old kindergarten students with larger numbers of subjects, and insights to apply linguistics particularly in English which can be used as a reference for the similar study. Perhaps, there will be found many different things.

\section{ACKNOWLEDGMENTS}

The researcher would like to thank first and foremost Allah swt. for His never ending grace; I wish to express my sincere appreciation to Dr. Siti Aisyah Ginting, M. Pd, and Dr. Rahmad Husein, M. Ed, for giving the researcher guidance, knowledge, and advice to finish this study with ease and also to researcher's parents and husband who are always there for financial support and they were the ones who showered researcher with encouragement, and also thanks to my colleagues at B-2 2017 English Applied Linguistic Study Program Universitas Negeri Medan, and the reviewers who have provided the opportunity for the researcher to share this research, in order for researcher to really do the best on this study. Without these people, this study wouldn't be successful or possible. That's why the researcher would like to say, "Thank you and May Allah swt. bless us all".

\section{REFERENCES}

[1] Arizona. The Acquisition of Sentences by Three Years Old Child, Thesis: State University of Medan. 2006.

[2] Bogdan, R. C., \& Bigden, S. K. Qualitative Research for Education. An Introduction to Theory and Methods. Syracuse University: Allyn and Bacon Spradley (1980:54). 1992.

[3] Bolinger, D. Aspect of Language. Second Edition. America: Harcourt Brace Jovanovich, Inc. 2002.

[4] Brown, K. Encyclopedia of Language and Linguistics Second Edition. Oxford: Elsevier. 2005.

[5] Chomsky, N. Knowledge of Language: Its Nature, Origin, and Use. New York: Praeger. 1986
[6] Frank, M. Modern English: Practical References Guide. New Jersey: Prentice Hall, Inc. 1972.

[7] Halle, M., \& Yang, C. D. Phonological Rules and the Storage of Words. MS, Massachusetts Institute of Technology and Yale University. 2002.

[8] Miles, M. \& Huberman, M. 1984. Qualitative Data Analysis. Beverly Hills, CA: Sage.1984.

[9] Salnita, Y. E. Pemerolehan Bahasa pada Anak Usia 3 Tahun. Thesis. Padang State University. 2019.

[10] Shopen, T. Language Typology and Syntactic Description. Cambridge University Press. 2007.

[11] Varshney, R. L. An Introductory Textbook of Linguistics \& Phonetic. India: Student Store. 2003. 